\title{
Thrombin causes endothelium-dependent biphasic regulation of vascular tone in the porcine renal interlobar artery
}

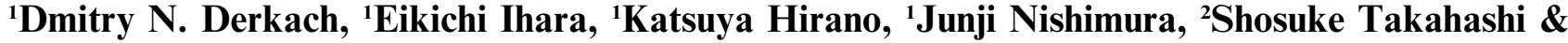 \\ *,1 Hideo Kanaide
}

${ }^{1}$ Department of Molecular Cardiology, Research Institute of Angiocardiology, Graduate School of Medical Sciences, Kyushu University, 3-1-1 Maidashi, Higashi-ku, Fukuoka, 812-8582 Japan and ${ }^{2}$ Department of Anesthesia and Critical Care Medicine, Graduate School of Medical Sciences, Kyushu University, 3-1-1 Maidashi, Higashi-ku, Fukuoka, 812-8582 Japan

1 Using a method employing front-surface fura-2 fluorometry to measure the cytosolic $\mathrm{Ca}^{2+}$ concentration, $\left[\mathrm{Ca}^{2+}\right]_{\mathrm{i}}$, the mechanism of endothelium-dependent regulation of vascular tone by thrombin was studied in porcine renal interlobar arterial strips.

2 At concentrations lower than $3 \mathrm{u} \mathrm{ml}^{-1}$, thrombin evoked only early transient relaxation, while at $3 \mathrm{u} \mathrm{ml}^{-1}$ and higher concentrations, thrombin caused an early relaxation and a subsequent transient contraction. Both thrombin-induced relaxation and contraction were abolished by removing the endothelium. Similar biphasic responses were observed with a protease-activated receptor-1activating peptide.

3 Early relaxation was associated with a decrease in $\left[\mathrm{Ca}^{2+}\right]_{\mathrm{i}}$, while the transient contraction was not associated with a change in $\left[\mathrm{Ca}^{2+}\right]_{i}$ of smooth muscle cells.

4 A thromboxane $\mathrm{A}_{2}\left(\mathrm{TXA}_{2}\right)$ / prostaglandin $\mathrm{H}_{2}\left(\mathrm{PGH}_{2}\right)$ receptor antagonist $\left(10^{-5} \mathrm{M} \mathrm{ONO}-3708\right)$ completely inhibited the thrombin-induced contraction, whereas a thromboxane $\mathrm{A}_{2}$ synthase inhibitor $\left(10^{-5}\right.$ M OKY-046) only partly inhibited it.

5 When the thrombin-induced contraction was inhibited by ONO-3708, either pretreatment with $\mathrm{N}^{\omega}$-nitro-L-arginine methylester (L-NAME) or an increase in the amount of external $\mathrm{K}^{+}$to $40 \mathrm{mM}$ did not abolish thrombin-induced relaxation during phenylephrine-induced sustained contraction. However, the combination of pretreatment with L-NAME and an elevation of external $\mathrm{K}^{+}$to $40 \mathrm{~mm}$ completely abolished the relaxation.

6 There was no significant difference in the concentration-dependent effects of thrombin on the initial early relaxation between conditions in which the contractile components either were or were not inhibited.

7 Thrombin is thus considered to mainly activate protease-activated receptor-1 and cause a biphasic response, early relaxation and a transient contraction, in the porcine renal interlobar artery in an endothelium-dependent manner. The thrombin-induced endothelium-dependent relaxation was mediated by nitric oxide and hyperpolarizing factors, while the contraction was mediated by $\mathrm{TXA}_{2}$ and $\mathrm{PGH}_{2}$.

British Journal of Pharmacology (2000) 131, $1635-1642$

Keywords: Renal artery; endothelial cells; $\mathrm{Ca}^{2+}$; thrombin; endothelium-dependent contraction; endothelium-dependent relaxation

Abbreviations: ANOVA, analysis of variance; $\left[\mathrm{Ca}^{2+}\right]_{i}$, cytosolic $\mathrm{Ca}^{2+}$ concentration; cPLC, cytosolic phospholipase $\mathrm{C}$; EDHF, endothelium-derived hyperpolarizing factor; EDRF, endothelium-derived relaxing factor; eNOS, endothelium constitutive nitric oxide syntase; fura-2/AM, acetoxymethylester form of fura-2; L-NAME, $\mathrm{N}^{\omega}$-nitro-L-arginine methylester; NO, nitric oxide; PAR, protease activated receptors; PAR-1-AP, PAR-1-activating peptide; $\mathrm{PGH}_{2}$, prostaglandin $\mathrm{H}_{2}$; PSS, physiological salt solution; TXA 2 , thromboxane $\mathrm{A}_{2}$

\section{Introduction}

Endothelial cells modulate the vascular tone by producing vasorelaxing and vasoconstricting factors. Endotheliumdependent relaxation has been studied in many species and different kinds of blood vessels. As a result, endotheliumdependent relaxations are known to be mediated by nitric oxide (NO) (Palmer et al., 1987), endothelium-derived hyperpolarizing factor (EDHF) (Chen \& Suzuki, 1989) or prostacyclin (Moncada et al., 1976). On the other hand, endothelium-dependent vasoconstriction has also been reported in specific combinations of vessel types and agonists. In the cerebral artery, A23187 (Shirahase et al., 1988), acetylcholine (Usui et al., 1993) and somatostatin (Shirahase et al., 1993) caused endothelium-dependent contractions. In

*Author for correspondence. the renal artery, acetylcholine (Nishimura et al., 1995), thapsigargin (Ihara et al., 1999) and bradykinin (Ihara et al., 2000) induced endothelium-dependent contractions. Nevertheless the precise mechanism and physiological role of endothelium-dependent contraction in blood vessels is still not clear.

Thrombin is a serine protease that converts fibrinogen into fibrin. It is also known as a potent agonist for platelet aggregation, macrophage chemotaxis, and mitogenesis of lymphocyte, fibroblasts or mesenchymal cells (Shuman, 1986). In the vascular system, thrombin has been reported to produce NO, EDHF and prostacyclin, while also causing endothelium-dependent relaxation (Lewis \& Miller, 1992; Mizuno et al., 1998; Nagao \& Vanhoutte, 1992; Vanhoutte et al., 1986). In the porcine renal artery and rabbit aorta, thrombin has been reported to have a direct effect on smooth 
muscle and thus cause contractions (Bretschneider et al., 1995; Godin et al. 1995). In the human umbilical vein, a PAR-2 activating peptide has been reported to induce an endothelium-dependent contraction (Saifeddine et al., 1998). However, there has yet to be any report on the endotheliumdependent contraction induced by thrombin.

These cellular effects of thrombin were mediated by a family of G-protein coupled receptors, protease-activated receptors (PARs). Four members of PARs have been isolated, and PAR-1, PAR-3 and PAR-4 were shown to be receptor for thrombin (Dery et al., 1998). The activation of PARs by thrombin are initiated by proteolytic cleavage of the extracellular domain, exposing the new N-termini, which in turn serve as tethered ligands (Dery et al., 1998). The synthetic peptides corresponding to the tethered ligands have been successfully used to activate PARs independent of cleavage.

In the present study, by simultaneously measuring the changes in $\left[\mathrm{Ca}^{2+}\right]_{i}$ of smooth muscle and the force in fura-2loaded strips with an intact endothelium, we demonstrated that thrombin induced not only an endothelium-dependent relaxation but also an endothelium-dependent contraction in the porcine renal interlobar artery. We investigated the mechanism of the thrombin-induced endothelium-dependent relaxation and contraction by using a $\mathrm{NO}$ synthase inhibitor, a thromboxane $\mathrm{A}_{2}\left(\mathrm{TXA}_{2}\right)$ / prostaglandin $\mathrm{H}_{2}\left(\mathrm{PGH}_{2}\right)$ receptor antagonist and a $\mathrm{TXA}_{2}$ synthase inhibitor. We also examined the effect of PAR-1 activating peptide (PAR-1-AP) on phenylephrine-induced contractions.

\section{Methods}

\section{Tissue preparation for front-surface fluorometry}

Porcine kidneys were freshly obtained from a local slaughterhouse and transported to the laboratory in the aerated icecold physiological salt solution (PSS). Thereafter, the renal interlobar arteries were dissected from the kidney and the adventitia was mechanically removed under a binocular microscope. The arterial segments thus obtained were opened longitudinally and cut into circular strips (approximately $1 \mathrm{~mm}$ wide, $3 \mathrm{~mm}$ long, $0.05 \mathrm{~mm}$ thick). Care was taken to avoid damaging the endothelium. To obtain strips without an endothelium, the inner surface was rubbed off with a cotton swab.

\section{Fura-2 loading of renal arterial strips}

The smooth muscle of the strips with and without an endothelium were loaded with fura-2, by incubating in Dulbecco's modified Eagle medium (Life technologies, Rockville, MD, U.S.A.) containing $25 \mu \mathrm{M}$ fura-2/AM (an acetoxymethylester form of fura- 2 ) and 5\% fetal bovine serum for $4 \mathrm{~h}$ at $37^{\circ} \mathrm{C}$, as previously described (Ihara et al., 1999). After loading with fura-2, the strips were rinsed with normal PSS to remove the dye in the extracellular space and then were equilibrated for at least $60 \mathrm{~min}$ at $37^{\circ} \mathrm{C}$ before starting the experimental protocols.

\section{Simultaneous measurement of $\left[\mathrm{Ca}^{2+}\right]_{i}$ and force of arterial strips}

Measurements of the changes in the fura- 2 fluorescence and force of arterial strips were carried out at $37^{\circ} \mathrm{C}$. The fura- 2 loaded strips were mounted vertically to a force transducer
TB-612T (Nihon Koden, Japan) in a quartz organ bath filled with normal PSS. Any changes in the level of $\left[\mathrm{Ca}^{2+}\right]_{i}$ of the smooth muscle in the arterial strips were monitored; using a front-surface fluorometer CAM-OF-3 (JASCO, Tokyo, Japan) as previously described (Kanaide, 1999; Ihara et al., 1999). The strips were illuminated by alternating $(400 \mathrm{~Hz})$ 340 and $380 \mathrm{~nm}$ excitation light from a xenon light source through quartz optic fibres. The surface fluorescence of the strips was collected by glass optic fibres and introduced through a $500 \mathrm{~nm}$ band pass filter (full width at half maximum transmission $=10 \mathrm{~nm}$ ) into a photomultiplier. The quartz and glass optic fibres were arranged in a concentric inner circle (3 mm diameter) and an outer circle $(7 \mathrm{~mm}$ diameter), respectively, at one end of the optic fibres facing to the strips. The fluorescence intensities $(500 \mathrm{~nm})$ at $340 \mathrm{~nm}$ (F340) and $380 \mathrm{~nm}(\mathrm{~F} 380)$ excitation and their ratio (F340/ F380), which indicated $\left[\mathrm{Ca}^{2+}\right]_{i}$ of smooth muscle, were continuously monitored. We previously showed the fura-2 signal to arise exclusively from the smooth muscle in the strips with an endothelium and that the signal derived from endothelial cells, if any, was negligible (Ihara et al., 1999).

During the $60 \mathrm{~min}$ equilibration periods, the strips were stimulated with $118 \mathrm{mM} \mathrm{K}^{+}$every $10 \mathrm{~min}$, and the resting load was increased in a stepwise manner and finally adjusted to $100 \mathrm{mg}$. When the renal artery was exposed to $10^{-6} \mathrm{M}$ phenylephrine in normal PSS, both $\left[\mathrm{Ca}^{2+}\right]_{\mathrm{i}}$ and the force rose rapidly and reached a peak within $1-3 \mathrm{~min}$, and thereafter slightly declined to reach a sustained level within $10 \mathrm{~min}$ (Figure 1a). This level was maintained for more than $30 \mathrm{~min}$. After the $\left[\mathrm{Ca}^{2+}\right]_{i}$ level and force returned to the resting level upon the removal of phenylephrine, the strip was stimulated once with $118 \mathrm{mM} \mathrm{K}^{+}$in order to refill the intracellular $\mathrm{Ca}^{2+}$ stores. Since the second stimulation with phenylephrine induced a similar contraction to that observed with the first stimulation, the response to the first stimulation with phenylephrine could be used as a reference response in the renal artery. The level of $\left[\mathrm{Ca}^{2+}\right]_{\mathrm{i}}$ and force at rest and at the sustained phase of the $10^{-6} \mathrm{M}$ phenylephrine-induced contraction were designated as $0 \%$ and $100 \%$, respectively.

\section{Drugs and solutions}

The composition of normal PSS was (in $\mathrm{mM}$ ): $\mathrm{NaCl} 123, \mathrm{KCl}$ 4.7, $\mathrm{NaHCO}_{3}$ 15.5, $\mathrm{KH}_{2} \mathrm{PO}_{4} 1.2, \mathrm{MgCl}_{2} 1.2, \mathrm{CaCl}_{2} 1.25$ and D-glucose 11.5 PSS was aerated with $95 \% \mathrm{O}_{2}$ and $5 \% \mathrm{CO}_{2}$, with the resulting $\mathrm{pH}$ to be 7.4 . PSS containing $118 \mathrm{mM} \mathrm{K}^{+}$ was prepared by replacing $\mathrm{NaCl}$ with equimolar $\mathrm{KCl}$. Fura-2/ AM was purchased from Dojindo Laboratories (Kumamoto, Japan). ONO-3708, a $\mathrm{TXA}_{2} / \mathrm{PGH}_{2}$ receptor antagonist and OKY-046, a $\mathrm{TXA}_{2}$ synthase inhibitor, were kindly donated by Ono Pharmaceutical Co. (Osaka, Japan). $\mathrm{N}^{\omega}$-nitro-Larginine methyl ester (L-NAME), phenylephrine, thrombin and hirudin were purchased from Sigma (St. Louis, MO, U.S.A.). PAR-1-AP, SFLLRNP, was purchased from Bachem (Budendorf, Switzerland). BQ-123, an endothelin receptor $\mathrm{ET}_{\mathrm{A}}$ antagonist, was purchased from RBI (Natick, MA, U.S.A.).

\section{Data analysis}

All data were expressed as the mean \pm s.e.mean. Since one arterial strip from one animal was used for each experiment, the number of experiments ( $n$ value) indicates the number of animals. All data were statistically analysed by the unpaired Student's $t$-test and an analysis of variance (ANOVA). $P$ values less than 0.05 were considered to be significant. A 


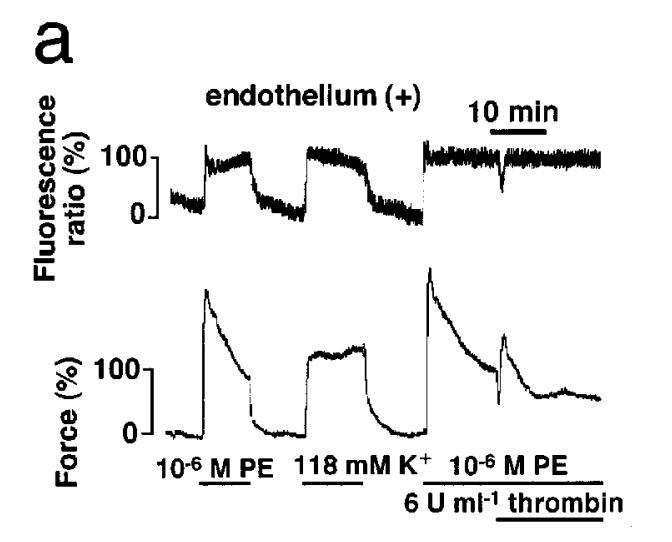

b
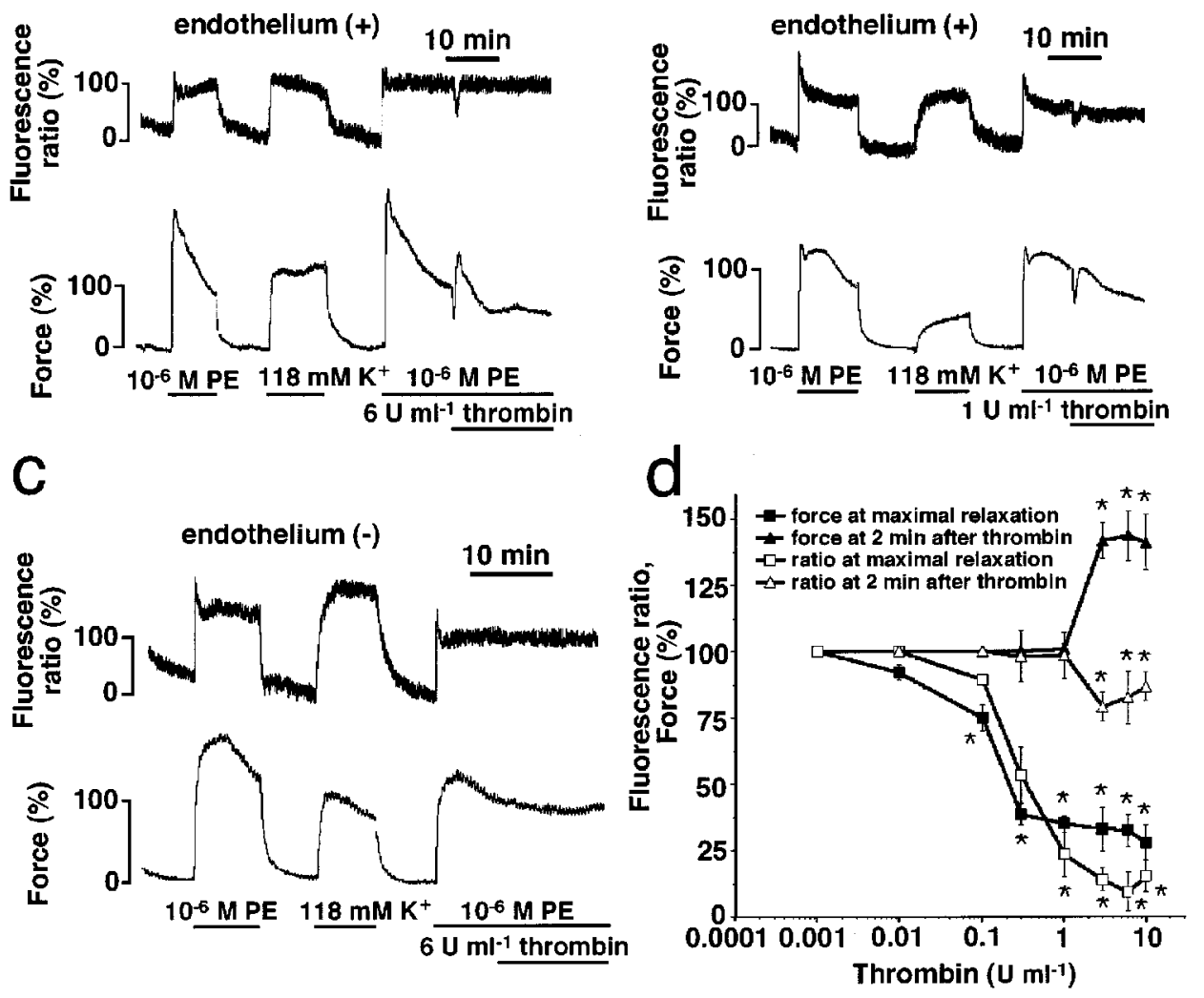

Figure 1 Thrombin-induced endothelium-dependent changes in $\left[\mathrm{Ca}^{2+}\right]_{\mathrm{i}}$ and the force during phenylephrine (PE)-induced sustained contraction in porcine renal arterial strips. (a, b) Representative recordings of the changes in $\left[\mathrm{Ca}^{2+}\right]_{i}$ and the force induced by $6 \mathrm{u} \mathrm{ml}^{-1}$ (a) and $1 \mathrm{u} \mathrm{ml}^{-1}$ (b) thrombin in the strips with an endothelium. (c) Representative recordings of changes in $\left[\mathrm{Ca}^{2+}\right]_{\mathrm{i}}$ and the force induced by $6 \mathrm{u} \mathrm{ml}^{-1}$ thrombin in arterial strips without an endothelium. The levels of $\left[\mathrm{Ca}^{2+}\right]_{\mathrm{i}}$ (fluorescence ratio) and force at rest and during the PE-induced sustained contraction were designated as $0 \%$ and $100 \%$, respectively. (d) Concentrationdependent effects of thrombin on $\left[\mathrm{Ca}^{2+}\right]_{\mathrm{i}}$ and force during the PE-induced sustained contraction in the porcine renal artery. All measurements were performed at a maximum level of early relaxation (relaxation ratio and relaxation force) and 2 min after application (ratio $2 \mathrm{~min}$ after thrombin and force $2 \mathrm{~min}$ after thrombin) at each concentration of thrombin. The data are the mean \pm s.e.mean $(n=6)$. ${ }^{*} P<0.05$ compared with PE-induced precontraction $(100 \%)$.

computerized data acquisition system (MacLab; Analog Digital Instruments, Australia, Macintosh; Apple Computer, U.S.A.) was used to collect the data.

\section{Results}

Thrombin-induced endothelium-dependent relaxation and contraction in porcine renal interlobar arterial strips

Figure 1a shows the representative recording of the changes in $\left[\mathrm{Ca}^{2+}\right]_{\mathrm{i}}$ and the force induced by $6 \mathrm{u} \mathrm{ml}^{-1}$ thrombin during the $10^{-6} \mathrm{M}$ phenylephrine-induced sustained contraction in the strips with endothelium. Thrombin induced an initial early relaxation with a subsequent transient contraction. Early relaxation was associated with a decrease in $\left[\mathrm{Ca}^{2+}\right]_{i}$, whereas transient contraction was associated with no increase in $\left[\mathrm{Ca}^{2+}\right]_{i}$. The initial early relaxation reached a maximum at $44.4 \pm 4.2 \mathrm{~s} \quad(n=6)$ after stimulation, and thereafter the level of the force returned to the level seen during the phenylephrine-induced sustained contraction at $84.0 \pm 5.0 \mathrm{~s}(n=6) .\left[\mathrm{Ca}^{2+}\right]_{\mathrm{i}}$ returned slightly slower than the force to the level seen during the $10^{-6} \mathrm{M}$ phenylephrineinduced contraction. The subsequent transient contraction reached its peak at $114.0 \pm 7.2 \mathrm{~s}(n=6)$ after the application of thrombin. At a lower concentration $\left(1 \mathrm{u} \mathrm{ml}^{-1}\right)$, thrombin induced only a transient early relaxation with a decrease in
$\left[\mathrm{Ca}^{2+}\right]_{\mathrm{i}}$, but no a subsequent transient contraction (Figure 1b). Removing the endothelium abolished both relaxation and contraction induced by thrombin in renal interlobar arterial strips (Figure 1c). In arterial strips without precontraction, $1 \mathrm{u} \mathrm{ml}^{-1}$ thrombin did not cause any significant changes in $\left[\mathrm{Ca}^{2+}\right]_{\mathrm{i}}$ and force, while $6 \mathrm{u} \mathrm{ml}^{-1}$ thrombin caused a transient contraction $(23.6 \pm 5.2 \%$, $n=6)$ without change in $\left[\mathrm{Ca}^{2+}\right]_{\mathrm{i}}$ level. The extent of this contraction was significantly $(P<0.05)$ smaller than that of the additional force development seen during the phenylephrine-induced contraction $(43.6 \pm 9.4 \%, \quad n=6)$. The thrombin-induced contraction seen at the baseline was abolished either by the removal of the endothelium or $10^{-5} \mathrm{M}$ ONO-3708 pretreatment of the arterial strips with endothelium (data not shown). When $30 \mathrm{u}$ thrombin were pretreated with $50 \mathrm{u}$ hirudin for $5 \mathrm{~min}$, and then were applied to the strip with the final concentration of thrombin and hirudin being 6 and $10 \mathrm{u} \mathrm{ml}^{-1}$, respectively, the thrombin failed to induce any relaxation or contraction (data not shown).

Figure 1d summarizes the concentration-dependent effects of thrombin on the initial relaxation and subsequent transient contraction. The relaxation was evaluated at the maximal level, and a subsequent transient contraction was evaluated at $2 \mathrm{~min}$ after the application of thrombin. A significant early relaxation was observed at $0.1 \mathrm{u} \mathrm{ml}^{-1}$ and higher concentrations of thrombin. At $0.1 \mathrm{u} \mathrm{ml}^{-1}$, thrombin 
induced an early relaxation $(75 \pm 4.9 \%, n=6) \quad(P<0.05)$ without any change in $\left[\mathrm{Ca}^{2+}\right]_{\mathrm{i}}$. The maximal early relaxation $(32.8 \pm 8.2 \%, n=6)$ was obtained at $3 \mathrm{u} \mathrm{ml}^{-1}$ thrombin, which was accompanied by a decrease in $\left[\mathrm{Ca}^{2+}\right]_{\mathrm{i}}(14 \pm 4.4 \%$, $n=6)$. There was no significant difference, among the levels of $\left[\mathrm{Ca}^{2+}\right]_{\mathrm{i}}$ and force obtained with 3,6 and $10 \mathrm{u} \mathrm{ml}^{-1}$ of thrombin, respectively. A significant subsequent transient contraction was observed at $3 \mathrm{u} \mathrm{ml}^{-1}$ and higher concentration of thrombin. The levels of $\left[\mathrm{Ca}^{2+}\right]_{\mathrm{i}}$ obtained with 3,6 and $10 \mathrm{u} \mathrm{ml}^{-1}$ thrombin-induced contractions were $79.3 \pm 5.4,82.5 \pm 10$ and $86.7 \pm 5.4 \%$, respectively $(n=6)$, while the levels of force were $141.6 \pm 6.7,143.6 \pm 9.4$ and $141 \pm 10.5 \%$, respectively $(n=6)$. There were no significant differences in the levels of $\left[\mathrm{Ca}^{2+}\right]_{i}$ and force among these concentrations. In the following experiments, we thus used $6 \mathrm{u} \mathrm{ml}^{-1}$ thrombin to investigate the mechanisms of the thrombin-induced endothelium-dependent relaxations and contractions.

The effects of a $\mathrm{TX}_{2} / \mathrm{PGH}_{2}$ receptor antagonist and a $\mathrm{TXA}_{2}$ synthase inhibitor on thrombin-induced endothelium-dependent contraction

To evaluate the mechanism of thrombin-induced contraction in the porcine renal interlobar arteries, the effects of a $\mathrm{TXA}_{2} / \mathrm{PGH}_{2}$ receptor antagonist $\left(10^{-5} \mathrm{M}\right.$ ONO-3708) and $\mathrm{TXA}_{2}$ synthase inhibitor $\left(10^{-5} \mathrm{M}\right.$ OKY-046) were examined.
Figure $2 \mathrm{a}, \mathrm{b}$ show representative recordings of the changes in the $\left[\mathrm{Ca}^{2+}\right]_{\mathrm{i}}$ and force induced by $6 \mathrm{u} \mathrm{ml}^{-1}$ thrombin in the presence of $10^{-5} \mathrm{M}$ ONO-3708 and $10^{-5} \mathrm{M}$ OKY-046, respectively. ONO-3708 and OKY-046 had no effect on the precontraction induced by phenylephrine. Pretreatment with $10^{-5} \mathrm{M}$ ONO-3708 completely inhibited the transient contraction induced by $6 \mathrm{u} \mathrm{ml}^{-1}$ thrombin (Figure 2a), while pretreatment with $10^{-5}$ M OKY-046 partly inhibited thrombin-induced contraction (Figure 2b). Because a transient contraction reached its peak at $114.0 \pm 7.2 \mathrm{~s}(n=6)$ after the application of thrombin in the absence of inhibitors (Figure 1), the effects of these inhibitors on the thrombin-induced contraction were evaluated at $2 \mathrm{~min}$. The levels of $\left[\mathrm{Ca}^{2+}\right]_{i}$ obtained in the presence of ONO-3708 and OKY-046 were $93.2 \pm 2.6$ and $102.4 \pm 2.6 \%,(n=6)$, respectively, and the levels of force were $96.2 \pm 1.7$ and $111.5 \pm 3.4 \% \quad(n=6)$, respectively (Figure 2c). The levels of force, in both cases, were significantly lower than those obtained in the absence of inhibitors (control level) $(P<0.05)$, while the $\left[\mathrm{Ca}^{2+}\right]_{\mathrm{i}}$ level did not significantly differ from the control level (Figure 2c). The level of force obtained with ONO-3708 did not significantly $(P<0.05)$ differ from that seen during the phenylephrine-induced precontraction. Pretreatment of arterial strips with indomethacin, a cyclo-oxygenase inhibitor, completely abolished the contraction induced by thrombin, while having no effect on the relaxation (data not shown). This observation was thus consistent with the complete
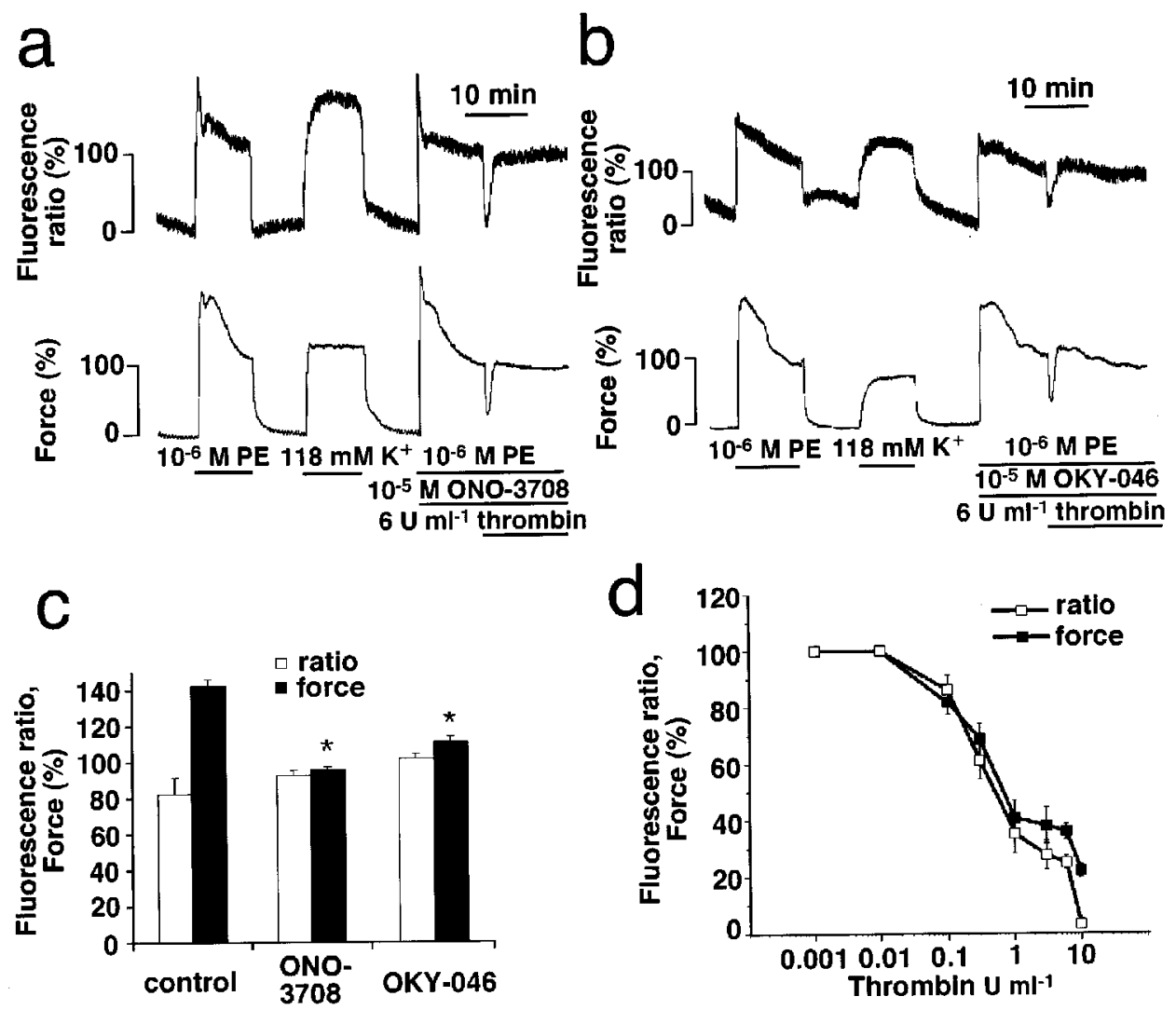

Figure 2 Effects of ONO-3708 (a thromboxane $\mathrm{A}_{2}$ /prostaglandin $\mathrm{H}_{2}$ receptor antagonist) and OKY-046 (a thromboxane $\mathrm{A}_{2}$ synthase inhibitor) on thrombin-induced endothelium-dependent contraction. (a,b) Representative recordings of the thrombininduced changes in $\left[\mathrm{Ca}^{2+}\right]_{\mathrm{i}}$ and force during phenylephrine (PE)-induced contraction in the presence of $10^{-5} \mathrm{M} \mathrm{ONO}-3708$ (a) and $10^{-5}$ M OKY-046 (b) in the porcine renal artery. The levels of $\left[\mathrm{Ca}^{2+}\right]_{\mathrm{i}}$ and force at rest and during PE-induced sustained contraction were designated as $0 \%$ and $100 \%$ respectively. (c) Summary of the effects of ONO-3708 and OKY -046 on [Ca $\left.{ }^{2+}\right]_{i}$ and force of the thrombin-induced endothelium-dependent contraction. All measurements were performed at 2 min after the application of thrombin (corresponding to the time of the peak contractile response). The data are the mean \pm s.e.mean $(n=6)$. $* P<0.05$ compared with the control level. (d) Concentration-dependent effects of thrombin on $\left[\mathrm{Ca}^{2+}\right]_{\mathrm{i}}$ and force of the PE-induced sustained contraction with $10^{-5}$ M ONO-3708 pretreatment in the porcine renal artery. The data are the mean \pm s.e.mean $(n=6)$. 
inhibition of the thrombin-induced contraction by ONO3708 .

In order to investigate whether or not thrombininduced contracting factors had any influence on the initial relaxation, we compared the concentration-response curves for the initial early relaxation between the presence (Figure 2d) and absence (Figure 1d) of ONO3708. The concentration-response curve obtained in the presence of ONO-3708 was similar to that obtained in its absence, thus suggesting that the thrombin-induced contracting factors had no effect on the extent of the maximal initial relaxation. However, ONO-3708 delayed the time course of recovery from the initial relaxation. The level of force returned to the level obtained during the phenylephrine-induced sustained contraction at $135.0 \pm 7.0 \mathrm{~s}(n=6)$ after the application of thrombin in the presence of ONO-3708. This value was significantly greater than that obtained in the absence of ONO-3708 $(84.0 \pm 5.0 \mathrm{~s}, n=6) \quad(P<0.05)$.

In order to rule out the involvement of endothelin in the thrombin-induced contraction, we examined the effects of BQ-123, an $\mathrm{ET}_{\mathrm{A}}$ receptor antagonist. BQ-123 abolished the contraction induced by endothelin-1 in the porcine renal interlobar artery, however, it had no effect on the thrombininduced contraction (data not shown).
Contribution of NO and EDHF to the thrombin-induced transient early relaxation

To elucidate the involvement of NO and EDHF in thrombininduced relaxation, the effects of L-NAME and an elevation of external $\mathrm{K}^{+}$were examined, respectively, while the thrombin-induced contraction was inhibited by $10^{-5} \mathrm{M}$ ONO-3708. Previously $40 \mathrm{mM}$ external $\mathrm{K}^{+}$was reported to be sufficient to eliminate the effects of EDHF in rat aorta and pulmonary artery (Chen \& Suzuki, 1989). In addition, $40 \mathrm{~mm}$ $\mathrm{K}^{+}$and $10^{-4} \mathrm{M}$ L-NAME were also reported to completely eliminate the effects of EDHF and $\mathrm{NO}$, respectively, produced by thapsigargin and bradykinin in the porcine renal interlobar artery with endothelium (Ihara et al., 1999; 2000). Both pretreatment with $10^{-4} \mathrm{M} \mathrm{L-NAME}$ (Figure 3a, d) and an increase of external $\mathrm{K}^{+}$to $40 \mathrm{mM}$ (Figure 3b,d) only partly abolished the thrombin-induced relaxation during the $10^{-6} \mathrm{M}$ phenylephrine-induced sustained contraction. However, the combination of $10^{-4} \mathrm{M} \mathrm{L}-\mathrm{NAME}$ and $40 \mathrm{mM}$ external $\mathrm{K}^{+}$completely abolished the thrombin-induced relaxation (Figure 3c,d). Since pretreatment with L-NAME and an elevation of external $\mathrm{K}^{+}$both augmented the phenylephrine-induced precontraction, the level of $\left[\mathrm{Ca}^{2+}\right]_{i}$ and force obtained just before the application of thrombin was assigned to be $100 \%$ in each experimental protocol

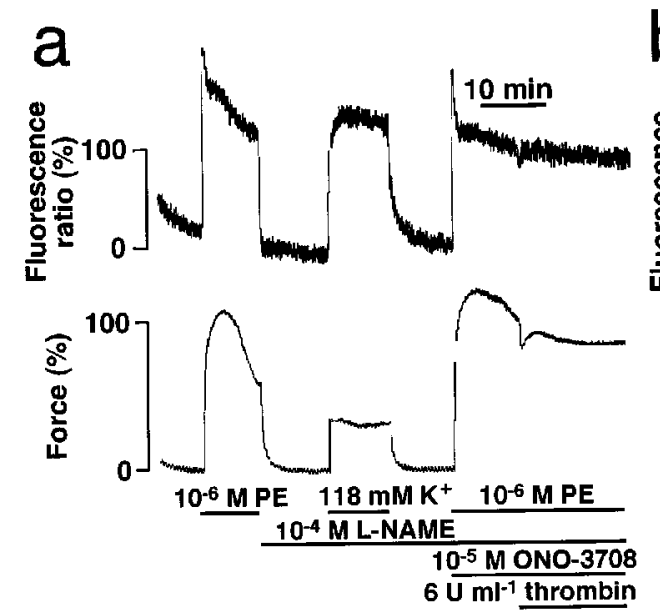

b
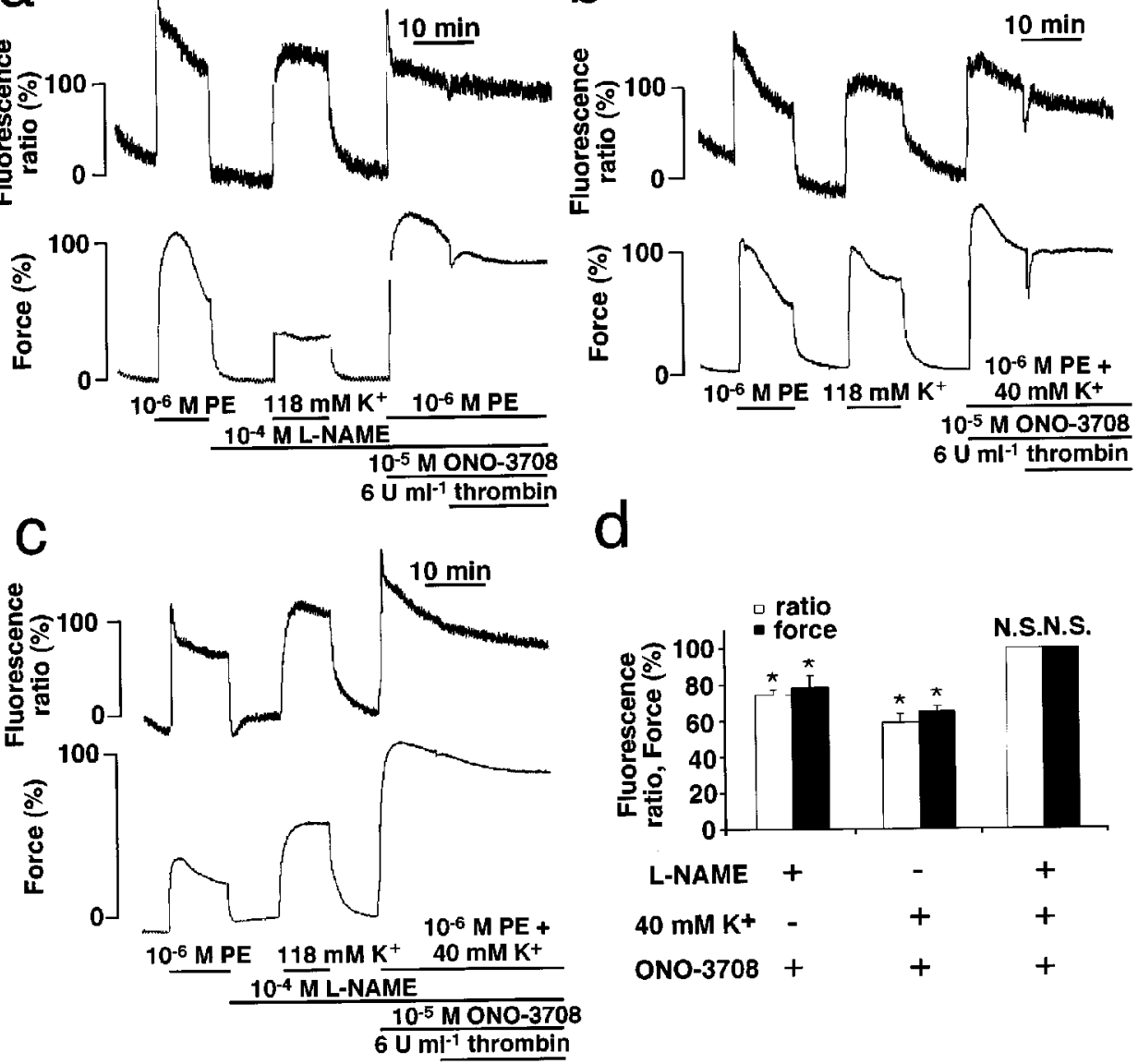

Figure 3 Effects of L-NAME and $40 \mathrm{mM} \mathrm{K}^{+}$on thrombin-induced endothelium-dependent relaxation. (a-c) Representative recordings of thrombin-induced changes in $\left[\mathrm{Ca}^{2+}\right]_{i}$ and force during phenylephrine (PE)-induced contraction in the presence of $10^{-4} \mathrm{M} \mathrm{L}-N A M E$ (a) $40 \mathrm{mM} \mathrm{K}{ }^{+}$(b) and combination of $10^{-4} \mathrm{M} \mathrm{L}-N A M E$ and $40 \mathrm{mM} \mathrm{K}^{+}$(c). The levels of [Ca $\left.{ }^{2+}\right]_{\mathrm{i}}$ and force at rest and during PE-induced sustained contraction just before application of thrombin were designated as $0 \%$ and $100 \%$, respectively. (d) Summary of the effects of L-NAME, $40 \mathrm{mM} \mathrm{K}{ }^{+}$and ONO-3708 on thrombin-induced endothelium-dependent relaxation. Measurements of $\left[\mathrm{Ca}^{2+}\right]_{\mathrm{i}}$ and force were performed at $44 \mathrm{~s}$ after the application of thrombin (transient relaxation). The data are the mean \pm s.e.mean $(n=6)$. ${ }^{*} P<0.05$ compared with the precontraction level. N.S., not significant. 
(Figure 3d). According to this assignment, the levels of $\left[\mathrm{Ca}^{2+}\right]_{\mathrm{i}}$ and force at the maximal relaxation obtained by the pretreatment with L-NAME in the presence of ONO-3708 were $74.2 \pm 2.5$ and $78.4 \pm 6.4 \%$, respectively $(n=6)$. In contrast, the levels obtained with $40 \mathrm{mM} \mathrm{K}^{+}$in the presence of ONO-3708 were $58.9 \pm 5.3$ and $64.7 \pm 2.9 \%$, respectively $(n=6)$. These values were all significantly $(P<0.05)$ lower than the precontraction level $(100 \%)$, whereas the values obtained in the combination of L-NAME and $40 \mathrm{mM} \mathrm{K}^{+}$did not significantly differ from the precontraction level $(100 \%)$ (Figure 3d).

To determine the involvement of prostacyclin in thrombininduced relaxation, the effect of indomethacin was examined. As a result, pretreatment with $10^{-5} \mathrm{M}$ indomethacin was found to have no effect on the thrombin-induced relaxation (data not shown).

\section{The effects of a PAR-1-activating peptide on the} phenylephrine-induced contraction in the porcine renal interlobar arterial strips

To elucidate the receptor subtype involved in the thrombininduced response, the effects of PAR-1-AP on the phenylephrine-induced contraction were examined (Figure 4). The PAR-1-AP, at $6 \times 10^{-5} \mathrm{M}$, induced a biphasic response (Figure 4a) similar to that observed with higher concentrations of thrombin (Figure 1a). An initial relaxation was accompanied by the decrease in $\left[\mathrm{Ca}^{2+}\right]_{i}$, while a transient contraction was not accompanied by the increase in $\left[\mathrm{Ca}^{2+}\right]_{\mathrm{i}}$. On the other hand, $3 \times 10^{-6} \mathrm{M}$ peptide induced only a transient relaxation (Figure $4 b$ ). These responses to the activating peptide were completely abolished by removing the endothelium (Figure 4c). Figure 4d summarizes the concentration-response curves for the PAR-1-AP-induced relaxations and contractions. The significant relaxation was observed at $3 \times 10^{-6} \mathrm{M}$ and higher concentrations, while the transient contraction was observed at concentrations higher than $10^{-5} \mathrm{M}$. PAR-1-AP as well as thrombin caused endothelium-dependent dual responses depending on the concentrations.

\section{Discussion}

In the present study we demonstrated that thrombin induced not only a relaxation, but also a contraction in an endothelium-dependent manner in the porcine renal interlobar artery. There have been many reports showing that thrombin causes an endothelium-dependent relaxation in various species and types of blood vessels (Lewis \& Miller, 1992; Nagao \& Vanhoutte, 1992; Vanhoutte et al., 1995). There have also been reports showing that thrombin caused endothelium-independent contraction in the porcine pulmonary artery (Bretschneider et al., 1995) and rabbit aorta

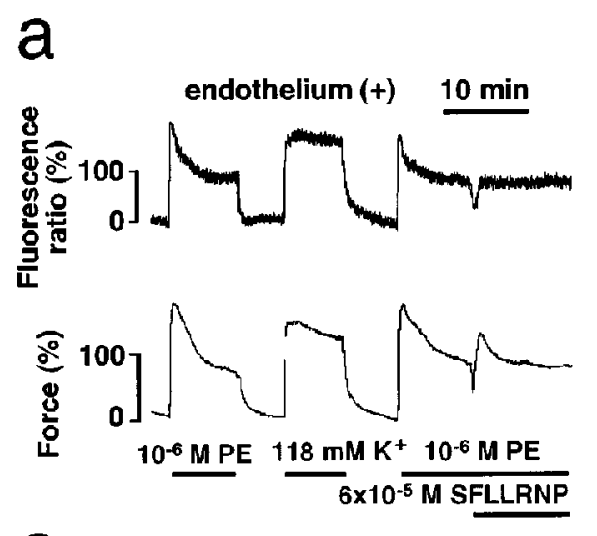

b
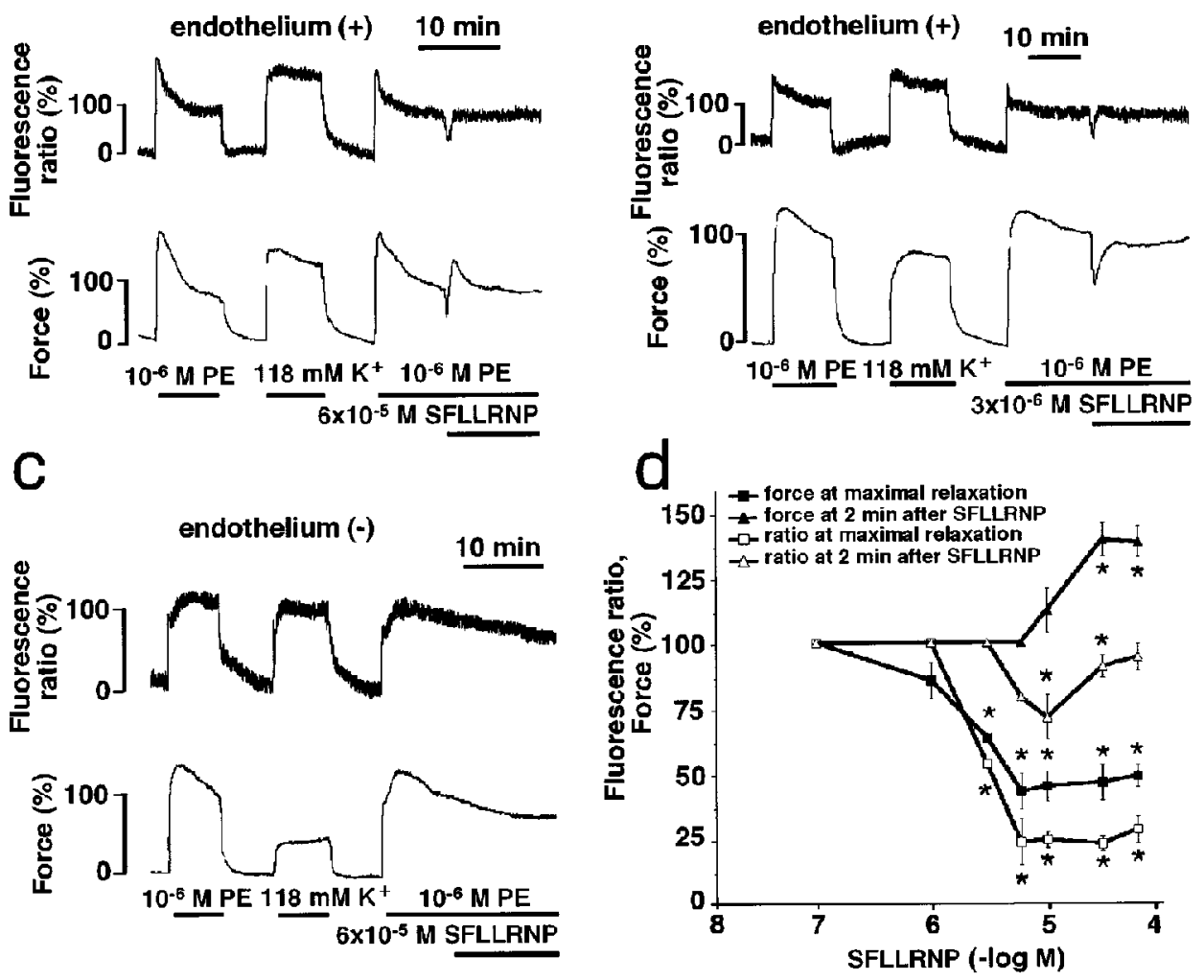

Figure 4 PAR-1-activating peptide (PAR-1AP): SFLLRNP induced endothelium-dependent changes in $\left[\mathrm{Ca}^{2+}\right]_{\mathrm{i}}$ and the force during phenylephrine (PE)-induced sustained contraction in porcine renal arterial strips. $(\mathrm{a}, \mathrm{b})$ Representative recordings of the changes in $\left[\mathrm{Ca}^{2+}\right]_{\mathrm{i}}$ and force induced by $6 \times 10^{-5} \mathrm{M}$ (a) and $3 \times 10^{-6} \mathrm{M}$ (b) PAR-1-AP (SFLLRNP) in the strips with an endothelium. (c) Representative recordings of changes in $\left[\mathrm{Ca}^{2+}\right]_{\mathrm{i}}$ and the force induced by $6 \times 10^{-5} \mathrm{M}$ PAR-1-AP in arterial strips without an endothelium. (d) Concentration-dependent effects of PAR-1-AP on $\left[\mathrm{Ca}^{2+}\right]_{i}$ and force during the PE-induced sustained contraction in the porcine renal artery. All measurements were performed at a maximum level of early relaxation and 2 min after application (ratio $2 \mathrm{~min}$ after SFLLRNP and force $2 \mathrm{~min}$ after SFLLRNP) at each concentration of SFLLRNP. The levels of $\left[\mathrm{Ca}^{2+}\right]_{\mathrm{i}}$ (fluorescence ratio) and force at rest and during the PE-induced sustained contraction were designated as $0 \%$ and $100 \%$, respectively. The data are the mean \pm s.e.mean $(n=6) .{ }^{*} P<0.05$ compared with PE-induced precontraction $(100 \%)$. 
(Godin et al., 1995). In the present study, thrombin-induced contraction was completely abolished by the removal of the endothelium, and thrombin had no direct effect on the smooth muscle of porcine renal interlobar artery, thus indicating that the effect of thrombin depended on the endothelium. The complete abolishment of the thrombininduced response by hirudin indicated the requirement of the proteolytic activity of thrombin, and thus suggests the involvement of PARs in the thrombin-induced responses. Although thrombin was shown to activate PAR-1, PAR-3 and PAR-4 (Dery et al., 1998), PAR-1-AP caused a biphasic response just similar to that observed with thrombin in the present study. This observation suggests that the thrombininduced response is mainly mediated by activating PAR-1.

$\mathrm{TXA}_{2}, \mathrm{PGH}_{2}$, endothelin and histamine are all reported to mediate endothelium-dependent contractions (Dai et al., 1992; Gruetter et al., 1994; Katusic \& Shepherd, 1991). In the present study, thrombin-induced contraction was completely inhibited by a $\mathrm{TXA}_{2} / \mathrm{PGH}_{2}$ receptor antagonist (Figure $2 \mathrm{~b}$ ) but not by endothelin receptor $\mathrm{ET}_{\mathrm{A}}$ antagonist, thus indicating that thrombin-induced contraction was mediated by $\mathrm{PGH}_{2}$ and/or $\mathrm{TXA}_{2}$. The relative contributions of $\mathrm{TXA}_{2}$ and $\mathrm{PGH}_{2}$ to endothelium-dependent contraction tend to vary with different types of stimulation (Buzzard et al., 1993; Kato et al., 1990). We previously reported that thapsigargin-induced contraction was mediated mainly by $\mathrm{TXA}_{2}$, while bradykinin-induced contraction was mediated by both $\mathrm{TXA}_{2}$ and $\mathrm{PGH}_{2}$ in the porcine renal interlobar artery (Ihara et al., 1999; 2000). In the present study, a partial inhibition of the contractile component by a $\mathrm{TXA}_{2}$ synthase inhibitor (Figure 2b) indicated that $\mathrm{TXA}_{2}$ and $\mathrm{PGH}_{2}$ were both involved in the thrombin-induced endothelium-dependent contraction, as in the case with bradykinin (Buzzard et al., 1993; Ihara et al., 1999; 2000; Kato et al., 1990).

It should be noted that thrombin-induced contraction was not associated with any concomitant increase in $\left[\mathrm{Ca}^{2+}\right]_{\mathrm{i}}$. The $\left[\mathrm{Ca}^{2+}\right]_{\mathrm{i}}$ level at the peak of contraction was still lower than the level seen during precontraction. These observations indicate that this contraction was mainly due to an increase in $\mathrm{Ca}^{2+}$-sensitivity of the contractile apparatus. We previously showed that $\mathrm{TXA}_{2}$ analogue, U-46619, and $\mathrm{PGH}_{2}$ induced greater force development for a given increase in $\left[\mathrm{Ca}^{2+}\right]_{\mathrm{i}}$ than high $\mathrm{K}^{+}$-depolarization in the porcine renal interlobar artery (Ihara et al., 1999; 2000). The potentiation of the $\mathrm{Ca}^{2+}$-sensitivity by the thrombin-induced contracting factors is thus consistent with the conclusion that $\mathrm{TXA}_{2}$ and $\mathrm{PGH}_{2}$ are the major contracting factors produced by thrombin in the endothelium of the renal interlobar artery.

We investigated the contribution of $\mathrm{NO}$ and EDHF to thrombin-induced relaxation by examining the effects of LNAME and $40 \mathrm{mM} \mathrm{K}^{+}$while thrombin-induced contraction was completely blocked by ONO-3708 (Figure $3 \mathrm{a}-\mathrm{d}$ ). The complete abolishment of relaxation was only achieved by the combination of $10^{-4} \mathrm{M}$ L-NAME and $40 \mathrm{mM} \mathrm{K} \mathrm{K}^{+}$, thus indicating that $\mathrm{NO}$ and EDHF contributed the most, if not completely, to the thrombin-induced relaxation. We previously reported that thrombin-induced endothelium-dependent relaxation was mediated by NO, EDHF and prostacyclin in the porcine coronary artery (Mizuno et al., 1998). Prostacyclin is responsible for a small sustained component of thrombin-induced relaxation in the porcine coronary artery (Mizuno et al., 1998). In the present study, thrombin induced only a transient relaxation even in the presence of ONO-3708, and indomethacin had no effect on the thrombin-induced relaxation. Collectively, the involve- ment of prostacyclin in the thrombin-induced relaxation is negligible, if present at all, and NO and EDHF account for most of the relaxation in the porcine renal artery.

The concentration-response curve for the maximal relaxation induced by thrombin was similar regardless of the presence or absence of the contractile component, thus indicating that contracting factors had no effect on the extent of early relaxation. However, the duration of the thrombin-induced relaxation extended in the presence of ONO-3708. These findings suggest that relaxing factors act first on the smooth muscle thereby inducing a transient relaxation, and thereafter the contracting factors start to act on smooth muscle and, as a result, overcome the effects of the relaxing factors and induce subsequent contraction. This difference in the timing of the action between the relaxing factors and contracting factors is considered to cause a biphasic response by thrombin in porcine renal interlobar artery.

We also noticed that higher concentrations of thrombin were required to induce contraction $\left(>3 \mathrm{u} \mathrm{ml}^{-1}\right)$ than those required to induce relaxation $\left(0.01\right.$ to $\left.10 \mathrm{u} \mathrm{ml}^{-1}\right)$. It is possible that dual thrombin receptor system mediated the dual effect of thrombin. However, PAR-1-AP induced a similar dual effect to those observed with thrombin. It is thus less likely that the different receptor subtype mediated the different responses to thrombin. On the other hand, the concentration-dependency observed for the thrombin-induced relaxation in the present study was similar to that observed for the thrombin-induced $\left[\mathrm{Ca}^{2+}\right]_{\mathrm{i}}$ elevation in the endothelial cells of the porcine aortic valve (Mizuno et al., 1998). Thrombin induced a transient $\left[\mathrm{Ca}^{2+}\right]_{i}$ elevation at concentrations higher than $0.1 \mathrm{u} \mathrm{ml}^{-1}$, while also inducing a maximal elevation of $\left[\mathrm{Ca}^{2+}\right]_{\mathrm{i}}$ at $3-6 \mathrm{u} \mathrm{ml}^{-1}$ (Mizuno et al., 1998). As a result, thrombin induced an endothelium-dependent contraction when the $\left[\mathrm{Ca}^{2+}\right]_{\mathrm{i}}$ elevation in endothelial cells reached a maximum. It is thus possible that the production of contracting factor requires higher elevation of $\left[\mathrm{Ca}^{2+}\right]_{\mathrm{i}}$ in endothelial cells. The key enzyme for the production of $\mathrm{TXA}_{2}$ and $\mathrm{PGH}_{2}$ is cytosolic phospholipase $\mathrm{A}_{2}\left(\mathrm{cPLA}_{2}\right)$, which releases arachidonic acid from phospholipid (Hirabayashi et al., 1999). The endothelial constitutive NO synthase (eNOS) is a key enzyme for production of NO. The activity of $\mathrm{cPLA}_{2}$ and eNOS are both regulated in a $\mathrm{Ca}^{2+}$-dependent manner (Kramer \& Sharp, 1997). eNOS is a $\mathrm{Ca}^{2+}$-calmodulindependent enzyme and its activity is thus closely regulated by the concentration of $\mathrm{Ca}^{2+}$. A brief and small increase in $\left[\mathrm{Ca}^{2+}\right]_{\mathrm{i}}$ due to $\mathrm{Ca}^{2+}$ release from the intracellular stores has been reported to be insufficient to activate $\mathrm{cPLA}_{2}$, but a larger and longer elevation of $\left[\mathrm{Ca}^{2+}\right]_{\mathrm{i}}$ due to $\mathrm{Ca}^{2+}$ influx was required (Hirabayashi et al., 1999). The requirement of a larger $\mathrm{Ca}^{2+}$ signal for activation of $\mathrm{CPLA}_{2}$ may account for the requirement of higher concentrations of thrombin to induce an endothelium-dependent contraction. It is also possible that intracellular signals other than $\mathrm{Ca}^{2+}$, which are activated at higher concentrations of thrombin, may be responsible for the production of such contracting factors. Recently, thrombin receptor has been shown to couple with a novel family of trimeric G-proteins, $\mathrm{G}_{12}$ (Aragay et al., 1995; Post et al., 1996) and activate small GTP-binding proteins such as Rho and Rac (Buhl et al., 1995; Collins et al., 1996). However, the involvement of the small GTP-binding protein in the activation of $\mathrm{cPLA}_{2}$ remains to be clarified.

In conclusion, we demonstrated that thrombin caused not only a relaxation but also a contraction in an endotheliumdependent manner in the porcine renal interlobar artery. At lower concentrations, thrombin caused a monophasic 
response of relaxation, while, at higher concentrations, it caused a biphasic response consisting of an initial relaxation and subsequent transient contraction. All of the thrombininduced responses were considered to be mainly mediated by PAR-1. The thrombin-induced endothelium-dependent relaxation was mediated by NO and EDHF, while contraction was mediated by $\mathrm{TXA}_{2}$ and $\mathrm{PGH}_{2}$. Thrombin is thus suggested to regulate the renal arterial tone in two different modes depending on the concentration.

\section{References}

ARAGAY, A.M., COLlinS, L.R., POST, G.R., WATSON, A.J., FERAMISCO, J.R., BROWN, J.H. \& SIMON, M.I. (1995). G G $_{12}$ requirement for thrombin-stimulated gene expression and DNA synthesis in $1321 \mathrm{~N} 1$ astrocytoma cells. J. Biol. Chem., 270, $20073-20077$.

BRETSCHNEIDER, E., PAINTZ, M. \& GLUSA, E. (1995). Involvement of inositol 1,4,5-triphosphate and protein kinase $\mathrm{C}$ in thrombininduced contraction of porcine pulmonary artery. Biochem. Pharmacol., 49, 33-38.

BUHL, A.M., JOHNSON, N.L., DHANASEKARAN, N. \& JOHNSON, G.L. (1995). $G_{\alpha 12}$ and $G_{\alpha 13}$ stimulate Rho-dependent stress fiber formation and focal adhesion assembly. J. Biol. Chem., 270 , $24631-24634$

BUZZARD, C.J., PFISTER, S.L. \& CAMPBELL, W.B. (1993). Endothelium-dependent contractions in rabbit pulmonary artery are mediated by thromboxane $\mathrm{A}_{2}$. Circ. Res., 72, 1023-1034.

CHEN, G. \& SUZUKI, H. (1989). Some electrical properties of the endothelium-dependent hyperpolarization recorded from rat arterial smooth muscle cells. J. Physiol., 410, 91-106.

COLLINS, L.R., MINDEN, A., KARIN, M. \& BROWN, J.H. (1996). G ${ }_{\alpha 12}$ stimulates c-Jun $\mathrm{NH}_{2}$-terminal kinase through the small $\mathrm{G}$ proteins Ras and Rac. J. Biol. Chem., 271, 17349-17353.

DAI, F.X., SKOPEC, J., DIEDERICH, A. \& DIEDERICH, D. (1992). Prostaglandin $\mathrm{H}_{2}$ and thromboxane $\mathrm{A}_{2}$ are contractile factors in intrarenal arteries of spontaneously hypertensive rats. Hypertension, 19, 795-798.

DERY, O., CORVERA, C.U., STEINHOFF, M. \& BUNNETT, N.W (1998). Proteinase-activated receptors: novel mechanisms of signaling by serine proteases. Am. J. Physiol., 274, C1429C1452.

GODIN, D., RIOUX, F., MARCEAU, F. \& DRAPEAU, G. (1995). Mode of action of thrombin in the rabbit aorta. Br. J. Pharmacol., 115, 903-908.

GRUETTER, C.A., LEMKE, S.M., VALENTOVIC, M.A. \& SZAREK, J.L. (1994). Evidence that histamine is involved as a mediator of endothelium-dependent contraction induced by A23187 in bovine intrapulmonary vein. Eur. J. Pharmacol., 257, 275-283.

HIRABAYASHI, T., KUME, K., HIROSE, K., YOKOMIZO, T., IINO, M. ITOH, H. \& SHIMIZU, T. (1999). Critical duration of intracellular $\mathrm{Ca}^{2+}$ response required for continuous translocation and activation of cytosolic phospholipase $\mathrm{A}_{2}$. J. Biol. Chem., 274, $5163-5169$.

IHARA, E., HIRANO, K., DERKACH, D.N., NISHIMURA, J., NAWATA, H. \& KANAIDE, H. (2000). The mechanism of bradykinininduced endothelium-dependent contraction and relaxation in the porcine interlobar renal artery. Br. J. Pharmacol., 129, $943-$ 952.

IHARA, E., HIRANO, K., NISHIMURA, J., NAWATA, H. \& KANAIDE, H. (1999). Thapsigargin-induced endothelium-dependent triphasic regulation of vascular tone in the porcine renal artery. $\mathrm{Br} . J$. Pharmacol., 128, 689-699.

KANAIDE, H. (1999). Measurement of $\left[\mathrm{Ca}^{2+}\right]_{\mathrm{i}}$ in smooth muscle strips using front-surface fluorimetry. Methods Mol. Biol., 114, $269-277$.

KATO, T., IWAMA, Y., OKUMURA, K., HASHIMOTO, H., ITO, T. \& SATAKE, T. (1990). Prostaglandin $\mathrm{H}_{2}$ may be the endotheliumderived contracting factor released by acetylcholine in the aorta of the rat. Hypertension, 15, 475-481.
We thank Mr Brian Quinn for comments and help with the manuscript. This study was supported in part by Grants-in-Aid for Scientific Research (No. 10557072, 11838013, 11670687) and for Scientific Research on Priority Area (No. 12213103) from the Ministry of Education, Science, Sports and Culture, Japan, by the Research Grant for Cardiovascular Diseases (11C-1) from the Ministry of Health and Welfare, Japan, and by grants from the Foundation for the Promotion of Clinical Medicine, the Suzuken Memorial Foundation and KANZAWA Medical Research Foundation.

KATUSIC, Z.S. \& SHEPHERD, J.T. (1991). Endothelium-derived vasoactive factors: II. Endothelium-dependent contraction. Hypertension, 18, III86-III92.

KRAMER, R.M. \& SHARP, J.D. (1997). Structure, function and regulation of $\mathrm{Ca}^{2+}$-sensitive cytosolic phospholipase $\mathrm{A}_{2}$ (cPLA $)$. FEBS Lett., 410, 49-53.

LEWIS, D.A. \& MILLER, V.M. (1992). Role of lipoxygenase and cytochrome $\mathrm{P}-450$ in production of endothelium-derived relaxing factors in canine femoral veins. J. Cardiovasc. Pharmacol., 20, $401-407$.

MIZUNO, O., HIRANO, K., NISHIMURA, J., KUBO, C. \& KANAIDE, H. (1998). Mechanism of endothelium-dependent relaxation induced by thrombin in the pig coronary artery. Eur. J. Pharmacol., 351, $67-77$.

MONCADA, S., GRYGLEWSKI, R., BUNTING, S. \& VANE, J.R. (1976). An enzyme isolated from arteries transforms prostaglandin endoperoxides to an unstable substance that inhibits platelet aggregation. Nature, 263, 663-665.

NAGAO, T. \& VANHOUTTE, P.M. (1992). Hyperpolarization as a mechanism for endothelium-dependent relaxations in the porcine coronary artery. J. Physiol., 445, 355-367.

NISHIMURA, Y., USUI, H., KURAHASHI, K. \& SUZUKI, A. (1995). Endothelium-dependent contraction induced by acetylcholine in isolated rat renal arteries. Eur. J. Pharmacol., 275, 217-221.

PALMER, R.M., FERRIGE, A.G. \& MONCADA, S. (1987). Nitric oxide release accounts for the biological activity of endotheliumderived relaxing factor. Nature, 327, 524-526.

POST, G.R., COLLINS, L.R KENNEDY, E.D., MOSKOWITZ, S.A., ARAGAY, A.M., GOLDSTEIN, D. \& BROWN, J.H. (1996). Coupling of the thrombin receptor to G12 may account for selective effects of thrombin on gene expression and DNA synthesis in $1321 \mathrm{~N} 1$ astrocytoma cells. Mol. Biol. Cell., 7, 1679-1690.

SAIFEDDINE, M., ROY, S.S., AL-ANI, B., TRIGGLE, C.R. \& HOLLENBERG, M.D. (1998). Endothelium-dependent contractile actions of proteinase-activated receptor-2-activating peptides in human umbilical vein: release of a contracting factor via a novel receptor. Br. J. Pharmacol., 125, $1445-1454$.

SHIRAHASE, H., KANDA, M., SHIMAJI, H., USUI, H., RORSTAD, O.P \& KURAHASHI, K. (1993). Somatostatin-induced contraction mediated by endothelial $\mathrm{TXA}_{2}$ production in canine cerebral arteries. Life Sci., 53, $1539-1544$.

SHIRAHASE, H., USUI, $\mathrm{H}$, KURAHASHI, K, FUJIWARA, M. \& FUKUI, K. (1988). Endothelium-dependent contraction induced by nicotine in isolated canine basilar artery-possible involvement of a thromboxane $\mathrm{A}_{2}\left(\mathrm{TXA}_{2}\right)$ like substance. Life Sci., 42, $437-445$.

SHUMAN, M.A. (1986). Thrombin-cellular interactions. Ann. NY. Acad. Sci., 485, 228-239.

USUI, H., KURAHASHI, K., SHIRAHASE, H., JINO, H. \& FUJIWARA, M. (1993). Endothelium-dependent contraction produced by acetylcholine and relaxation produced by histamine in monkey basilar arteries. Life Sci., 52, $377-387$.

VANHOUTTE, P.M., RUBANYI, G.M., MILLER, V.M. \& HOUSTON, D.S. (1986). Modulation of vascular smooth muscle contraction by the endothelium. Annu. Rev. Physiol., 48, 307-320.

(Received May 16, 2000 Revised September 14, 2000 Accepted September 22, 2000) 